\title{
Effect of altitude and seabuckthorn (Hippophae rhamnoides) on soil properties in dry temperate region of Himachal Pradesh
}

\author{
Abhay Sharma* and Virendra Singh \\ ${ }^{1}$ Department of Biology and Environmental Sciences, College of Basic Sciences, CSK Himachal Pradesh Krishi \\ Vishvavidyalaya, Palampur-176062 (Himachal Pradesh), INDIA \\ *Corresponding author. E-mail: abhayevs@gmail.com \\ Received: December 7, 2016; Revised received: June 10, 2017; Accepted: October 13, 2017
}

\begin{abstract}
Seabuckthorn (Hippophae rhamnoides) is an ecologically and economically important plant species used for the enhancement of soil fertility, prevention of soil erosion and production of food and medicinal products in mountain ecosystem. Altitude and landuse are the major factors which conditions the nutrient status of soil. In the study six different altitudes ( $3390 \mathrm{~m}, 3520 \mathrm{~m}, 3560 \mathrm{~m}, 3615 \mathrm{~m}, 3790 \mathrm{~m}$ and $4040 \mathrm{~m}$ ) above sea level in dry temperate region of Himachal Pradesh and three land use pattern viz., (seabuckthorn forest, willow forest and wasteland) were selected for the study and their impact was investigated on soil fertility. Soil properties such ( $\mathrm{pH}$, organic carbon, available macronutrients $\mathrm{N}, \mathrm{P}, \mathrm{K}, \mathrm{S}$ and exchangeable cations $\mathrm{Ca}, \mathrm{Mg}$ ) were determined following the standard procedures. The values of soil available nutrients under seabuckthorn varied as $\mathrm{pH}$ (8.2 to 7.8), organic carbon (1.05 to 2.35 per cent) N (125 to $\left.205 \mathrm{~kg} \mathrm{ha}^{-1}\right), \mathrm{P}\left(15\right.$ to $\left.31 \mathrm{~kg} \mathrm{ha}^{-1}\right), \mathrm{K}\left(94\right.$ to $\left.284 \mathrm{~kg} \mathrm{ha}^{-1}\right), \mathrm{S}\left(28\right.$ to $\left.53 \mathrm{~kg} \mathrm{ha}^{-1}\right)$, exchangeable $\mathrm{Ca}\left(8.56\right.$ to $\left.10.20 \mathrm{cmol}(\mathrm{p}+) \mathrm{kg}^{-1}\right)$ and $\mathrm{Mg}\left(2.3\right.$ to $\left.3.6 \mathrm{cmol}(\mathrm{p}+) \mathrm{kg}^{-1}\right)$, respectively. The soil nutrients in seabuckthorn forest were found much higher than willow forest and wasteland, especially organic carbon and available $\mathrm{N}$ contents. Soil nutrients were found to increase with increasing altitude and decrease with increasing soil depth. The results concluded that Hippophae rhamnoides had significant effects $(p<0.05)$ on soil nutrient conditions. Hence our study indicates that seabuckthorn has a big potential for soil conservation, ecological sustainability and restoration of Himalayan ecosystem.
\end{abstract}

Keywords: Altitude, Cold desert, Hippophae rhamnoides, Resource management, Soils

\section{INTRODUCTION}

The diverse climate and the varied environmental conditions prevailing in cold desert support distinct habitat and ecosystems with equally diverse life forms. But this unique and the most beautiful corner of the Himalayas is under threat due to various environmental challenges prevailing in the region, which include the poor water management, soil erosion and degradation of soil fertility. Also, climate change is one of the reasons to cause extreme events such as storms, landslides, avalanches and rock falls in these mountain areas which will threaten the eco sensitive zone (Kohler et al., 2010). The degradation of this ecosystem is due to decrease of biodiversity, disappearance of natural vegetation and change of soil structure. The frequent landslides and droughts in the fragile ecosystem often lead to fast depletion of existing forest cover. The degradation of the soil resources i.e. soil erosion, poor soil structure, decreased soil water content and loss of soil fertility, respectively are accounted as one of the real problems. So there is need of conservation and improvement to maintain the deteriorating ecosystem.

Considering all these challenges, seabuckthorn is the best choice. Seabuckthorn (Hippophae rhamnoides L.) is a native shrub from Eurasia which belongs to family Elaeagnaceae is a hardy, deciduous, nitrogen fixing, medicinal shrub. It is currently domesticated in many parts of the world like China, Russia, Mongolia, India, Nepal, Pakistan, Afghanistan, Hungary, Romania, Switzerland, Germany, France, Britain, Finland, Sweden, Norway and Canada. It is widely distributed in high altitudes and temperate areas of Himachal Pradesh, Jammu \& Kashmir, Uttrakhand, Sikkim and Arunachal Pradesh in India (Singh, 2003; Kumar et al., 2015).

Three species of seabuckthorn are found in Indian Himalaya Hippophae rhamnoides ssp. turkestanica, $H$. salicifolia and $H$. tibetana which are extremely tolerant to freezing condition (Sharma et al., 2015). Seabuckthorn berries are the richest source of vitamins (A, C, E and $\mathrm{K}$ ), different bioactive phytochemicals (sugars, amino acids, organic acids and fatty acids), antioxidants, unsaturated fatty acids, sterols and phenolic compounds (Kallio et al., 2002; Anderson et al., 2009; Rongsen, 2014).

Seabuckthorn is an early succession plant and has physiological mechanisms to grow under environmental stresses such as drought, water-logging, salinity, 
alkalinity and cold conditions (Singh and Gupta, 1990; Yao and Tigerstedt, 1995). It has an extraordinary capacity to grow and survive under adverse conditions (40 to $40^{\circ} \mathrm{C}$ ) and can exist in different types of soils and stress conditions, such as unfertile to barren land (Yadav and Deswal, 2007). Also, the shrub develops an extensive root system having symbiotic association with microorganism belonging to the genus Frankia which has the ability to fix $180 \mathrm{~kg}$ of nitrogen / hectare / year and generally improves soil fertility (Stobdan et al., 2008; Tamchos and Kaul, 2015; Yu et al., 2015).

Seabuckthorn plantation has played a crucial role in improving the soil health with the enrichment in soil organic matter that is one of the important nutrients to soil which leads to increase in soil fertility (Guo et al., 2003; Gong et al., 2007; Mishra et al., 2009). Seabuckthorn plantation act as soil binder, reduces soil erosion, improves soil fertility, adds organic matter in soil with the decomposition of leaves and dead roots and can adapt itself in any condition. It has high growth rate, indicating as a good choice for activating soil development in the early stage of reclamation and different studies showed that the values of organic carbon levels in the top soil layer were higher than the below layers (Zhao et al., 2013a).

There are ample opportunities to bring change in the livelihoods of mountain people by utilizing this kind hidden treasure of the Himalayas (Khosla et al., 1994; Acharya et al., 2010). Land reclamation and ecological restoration of this fragile ecosystem is urgent and need of the hour. Thus, seabuckthorn plantation qualifies as a unique option for the simultaneous management of several problems emanating from the fragility, marginality, inaccessibility and diversity characterising mountain areas (Rongsen, 1992). This study aims to test the significance of seabuckthorn plantation on soil environment, soil physical and chemical nutrient conditions.

\section{MATERIALS AND METHODS}

The present study was carried out in Spiti, with an area of $5,582 \mathrm{sq} \mathrm{km}$, is located between $31^{\circ} 42^{1}-32^{\circ} 58^{1} \mathrm{~N}$ latitude and $77^{\circ} 21^{1}-78^{\circ} 35^{1} \mathrm{E}$ longitude in the extreme North-East region of Himachal Pradesh situated between mountain ranges of Great and Middle Himalayas. Lying in the rain shadow of the mighty Himalayas, Spiti is a cold desert at an average of $4000 \mathrm{~m}$ above sea level, receives scanty rainfall valley, experience extremes of climate and temperature variations ranging from $-43^{\circ} \mathrm{C}$ to $+40^{\circ} \mathrm{C}$. For more than 4 months of the year the Spiti valley remain obscured by harsh winter.

The field experiment was carried out in 6 places at different altitudes in an elevation range 3390-4040 m above sea level in Spiti valley. Soil samples at the depths of $0-10 \mathrm{~cm}, 10-20 \mathrm{~cm}$ and $20-30 \mathrm{~cm}$ were col-

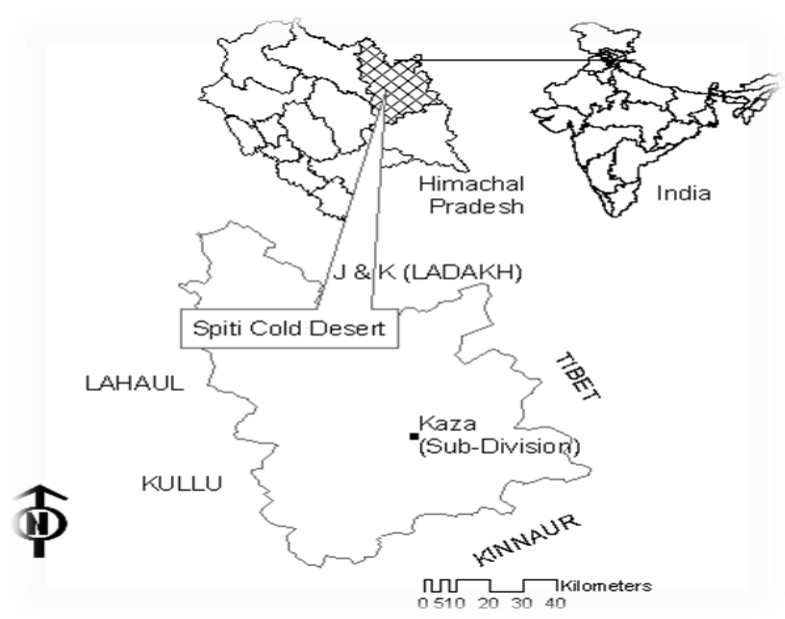

Fig. 1. Map of the Spiti, Himachal Pradesh.

lected under seabuckthorn (Hippophae rhamnoides), willow (Salix daphnoides) forest and wasteland. Soil samples were collected from the different locations such as Tabo (3390 m asl), Shichling (3520 m asl), Lingti (3560 m asl), Shego (3615 m asl), Rangrik (3790 $\mathrm{m}$ asl) and Hansa (4040 m asl) with increasing altitude chosen randomly with help of soil auger and were thoroughly mixed together each samples weighing about $200 \mathrm{~g}$ and subsequently stored in polythene bags for the determination of soil properties. Chemical analysis was carried out in Department of Soil Science laboratory, CSKHPKV, Palampur.

Standard procedures were used to measure the soil parameters such as $\mathrm{pH}$, organic carbon, available $\mathrm{N}, \mathrm{P}$, $\mathrm{K}, \mathrm{S}$ and exchangeable $\mathrm{Ca}, \mathrm{Mg}$ were measured in chemical analysis. The organic carbon was measured using $\mathrm{K}_{2} \mathrm{Cr}_{2} \mathrm{O}_{7}$ method (Walkley and Black, 1934) and the available $\mathrm{N}$ was estimated by using the method of Kjeldahl extraction, the available $P$ was measured by Olsen's method with spectrophotometer (Olsen et al., 1954), available K was estimated by using Atomic Absorption Spectrophotometer. Statistical analysis was done as per (Gomez and Gomez, 1984).

\section{RESULTS AND DISCUSSION}

Variation of different soil nutrients with altitude under seabuckthorn in Spiti: Soil characteristics varied greatly in seabuckthorn forest, willow forest and wasteland, from different altitudes $(3390 \mathrm{~m}, 3520 \mathrm{~m}$, $3560 \mathrm{~m}, 3615 \mathrm{~m}, 3790 \mathrm{~m}$ and $4040 \mathrm{~m}$ above sea level) and depth layers in Spiti valley. A perusal of Table 1 and Fig. 2 showed that soil $\mathrm{pH}$ under seabuckthorn forest significantly decreased with an increase in altitude and increased with an increase in soil depth. The soil $\mathrm{pH}$ was alkaline in reaction and similar findings have been reported by Sharma and Kanwar (2010) and Sharma (2011). Soil organic carbon is an important index to reflect the soil fertility. The calculated value for organic carbon in seabuckthorn soils ranged from 1.05 to 2.28 per cent. The organic carbon in the forest 
Abhay Sharma and Virendra Singh / J. Appl. \& Nat. Sci. 9 (4): 2228 - 2234 (2017)
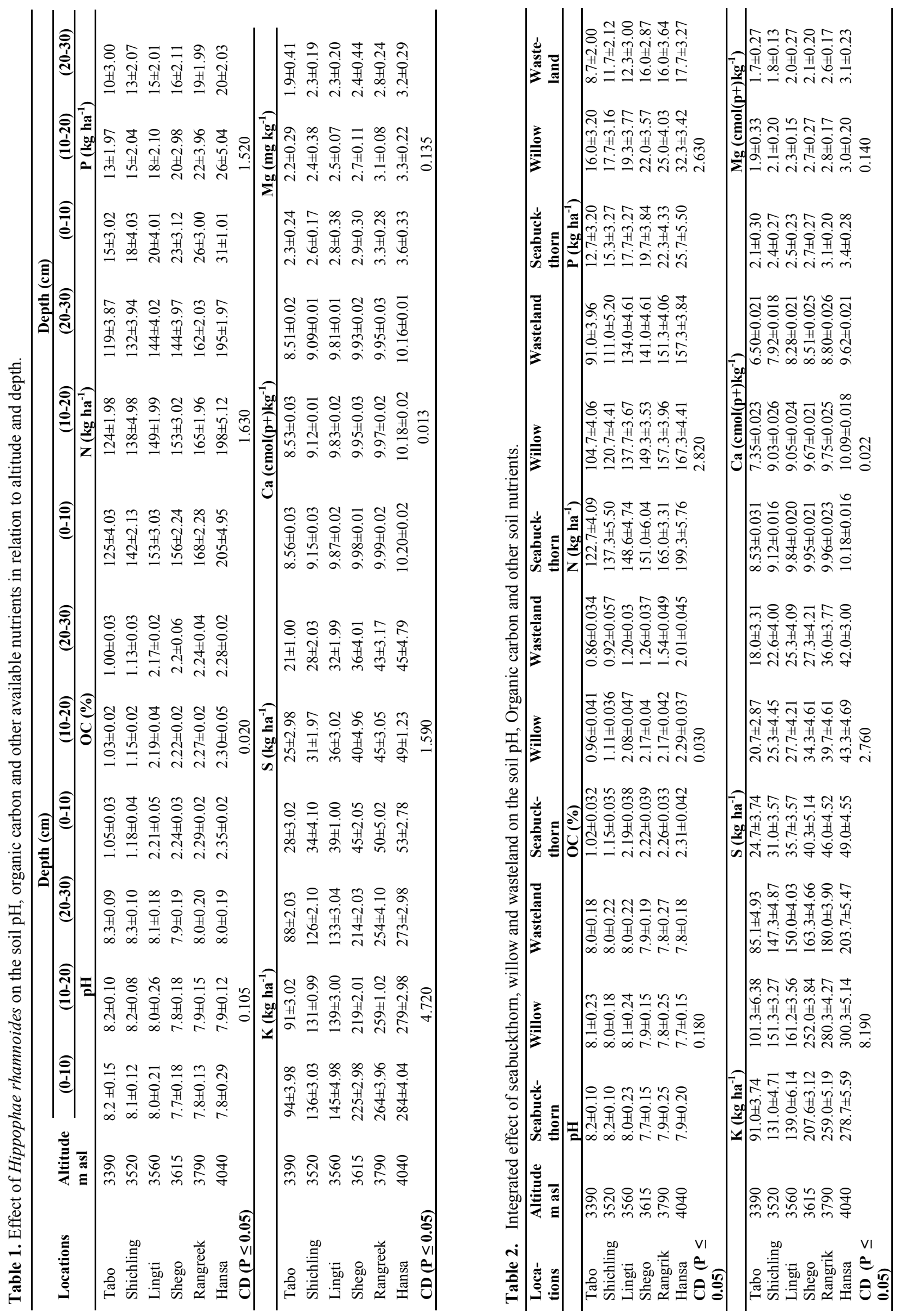
Abhay Sharma and Virendra Singh / J. Appl.\& Nat. Sci. 9 (4): 2228 - 2234 (2017)

Table 3. Correlation between $\mathrm{pH}, \mathrm{OC}$ and other available soil nutrients with each other under seabuckthorn vegetation.

\begin{tabular}{|c|c|c|c|c|c|c|c|c|}
\hline Correlation & pH & $\mathrm{OC}$ & $\mathbf{N}$ & $\mathbf{P}$ & K & $\mathbf{S}$ & $\mathrm{Ca}$ & Mg \\
\hline $\mathrm{pH}$ & 1 & $-0.653 * *$ & $-0.504^{*}$ & $-0.689 * *$ & $-0.608 * *$ & $-0.598 * *$ & $-0.648^{* *}$ & $-0.506^{* *}$ \\
\hline $\mathrm{OC}$ & & 1 & $0.749 * *$ & $0.653^{* *}$ & $0.787 * *$ & $0.815^{* *}$ & $0.965 * *$ & $0.659 * *$ \\
\hline $\mathrm{N}$ & & & 1 & $0.798^{* *}$ & $0.884 * *$ & $0.882 * *$ & $0.819^{* *}$ & $0.868 * *$ \\
\hline$P$ & & & & 1 & $0.756^{* *}$ & $0.791 * *$ & $0.700 * *$ & $0.839 * *$ \\
\hline K & & & & & 1 & $0.883 * *$ & $0.836 * *$ & $0.807 * *$ \\
\hline S & & & & & & 1 & $0.851 * *$ & $0.883 * *$ \\
\hline $\mathrm{Ca}$ & & & & & & & 1 & $0.709 * *$ \\
\hline $\mathrm{Mg}$ & & & & & & & & 1 \\
\hline
\end{tabular}

** Significant level: $0.05, \mathrm{r}=>0.468, \quad *$ Significant level: $0.01, \mathrm{r}=>0.589$

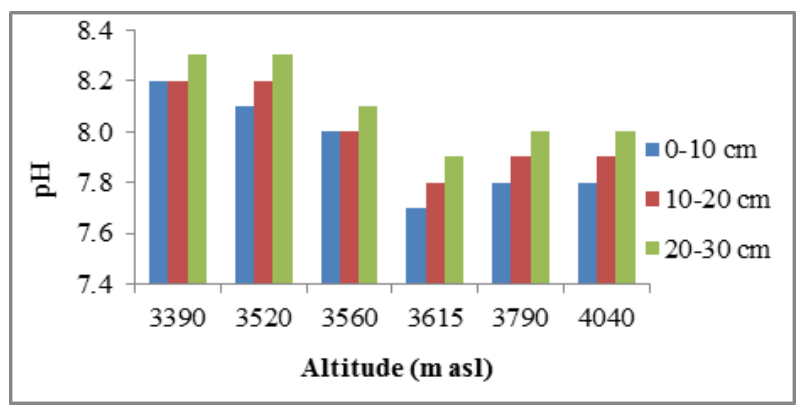

(a) $\mathrm{pH}$

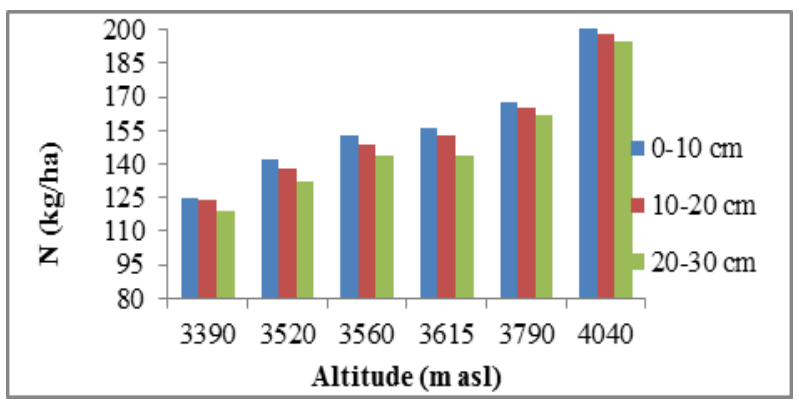

(c) Available N

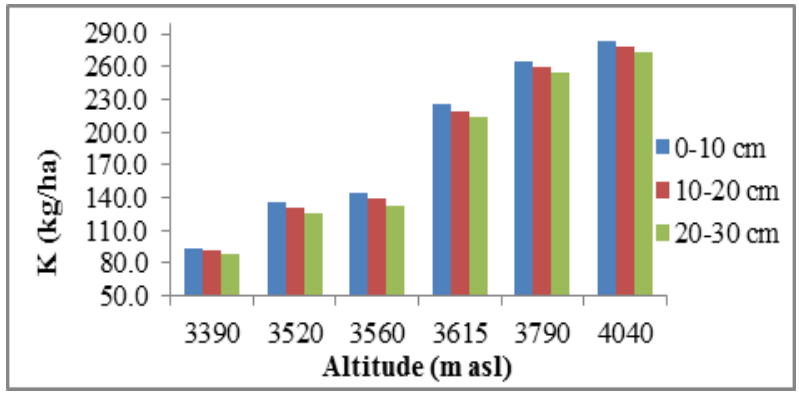

(e) Available K

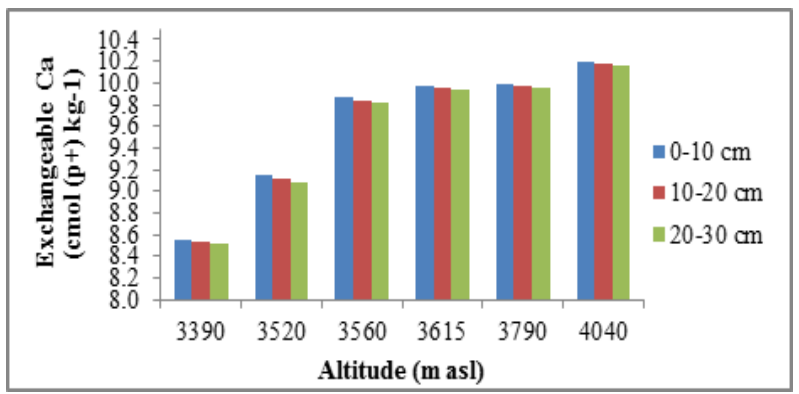

(g) Exchangeable $\mathrm{Ca}$

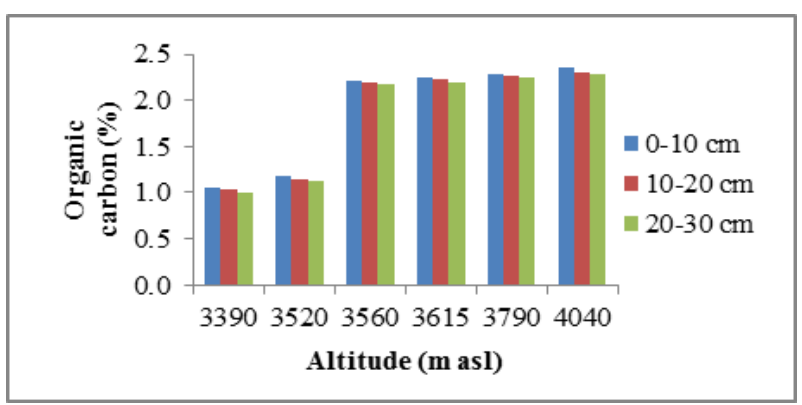

(b) Organic carbon

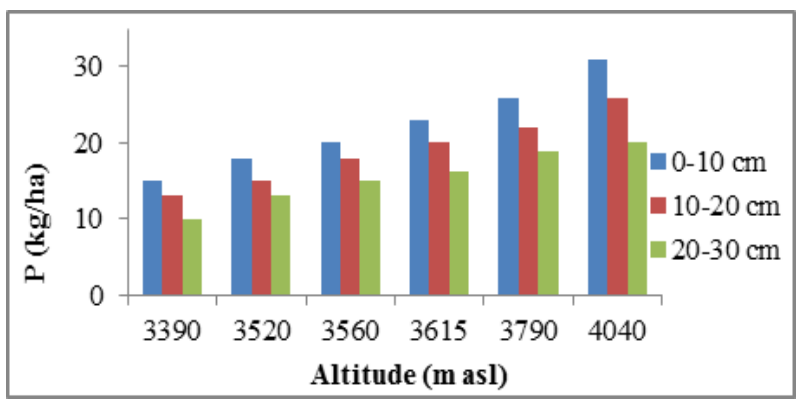

(d) Available P

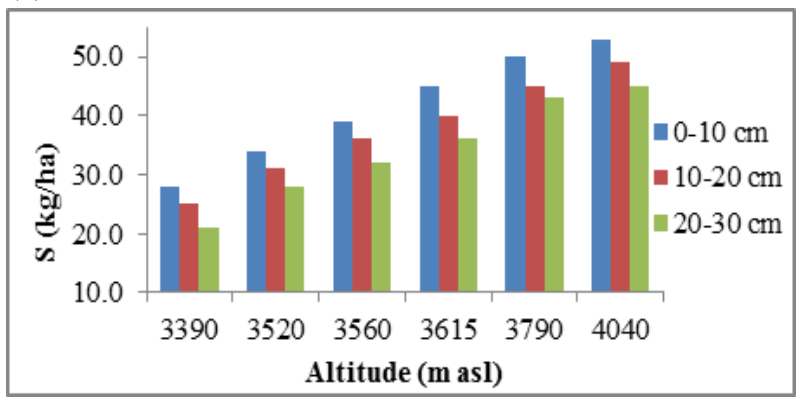

(f) Available S

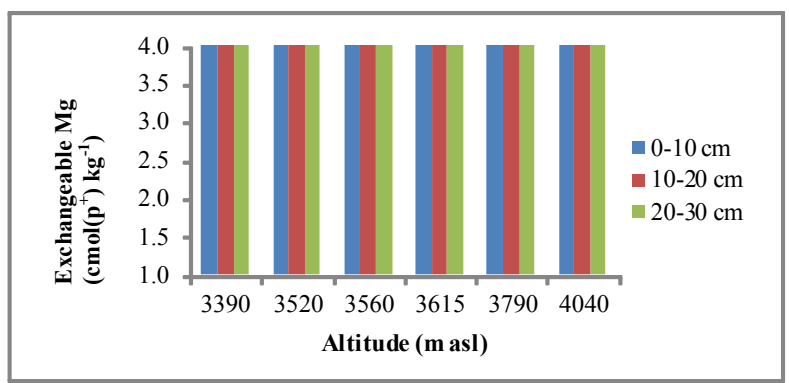

(h) Exchangeable $\mathrm{Mg}$

Fig. 2. Variations of different soil nutrients in relation to altitude under wasteland and forest land in Spiti. 
of seabuckthorn mainly concentrates in the top soil layer, about $1.05-2.35$ per cent. The contents of the middle layer and the sub layer are just a little, taking up about $1.03-2.30$ per cent and $1.00-2.28$ per cent (Table 1). Also, soil organic carbon significantly increased with an increase in altitude and decreased with an increase in depth of soil (Fig. 2). The increasing and decreasing trend of organic carbon with respect to altitude and soil depth is because of development of above -ground plants and roots, underground roots, leaf litter, the surface and underground secretions which became important sources of soil organic carbon and there slow decomposition under low temperature, which is one of the reason of accumulation of organic carbon in the top soils than in subsurface soils (Gong et al., 2007; Ali et al., 2013; Zhao et al., 2013b; Bi and Zhang, 2014; Khan et al., 2015).

Available nitrogen in seabuckthorn soils varied from 125 to $195 \mathrm{~kg} \mathrm{ha}^{-1}$ and was found to increase with increasing altitude. As a result of seabuckthorn effects on fixing nitrogen, available $\mathrm{N}$ contents in the seabuckthorn forest are very high in the topsoil (125$205 \mathrm{~kg} \mathrm{ha}^{-1}$ ) and decreased with increasing soil depth, taking up about $124-198 \mathrm{~kg} \mathrm{ha}^{-1}$ in the middle layer and $119-195 \mathrm{~kg} \mathrm{ha}^{-1}$ in the sub layer (Table 1 and Fig. 2). Similarly, the Available macronutrients $P, K$ and $S$ in the soil were found to increase with an increase in altitude and decrease with an increase in soil depth. Seabuckthorn has an ability to increase the content of available nitrogen in soil and improve soil fertility through nitrogen fixation by nitrogen fixing bacteria Frankia (Bi and Zhang, 2014). The soil available N increased as altitude increases same is the data recorded by (Biddapa and Rao, 1973) and also, similar results were shown for available P and K by (Guo, 2003; Sharma, 2011; Zhao et al., 2013b). Also, available S content increased with increasing altitude due to the addition of leaf litter annually and slow decomposition of organic residues under low temperature which results in increase in S contents (Sharma, 2011).

Exchangeable cations such as $\mathrm{Ca}$ and $\mathrm{Mg}$ were also found to increase with an increase in altitude and decrease with an increase in soil depth (Table 1 and Fig. 2). Similar results were found by (Singh and Raman, 1982; Sharma, 2011), who found a decreasing order of exchangeable $\mathrm{Ca}$ and $\mathrm{Mg}$ with depth. It might be due to mild leaching of $\mathrm{Ca}$ and $\mathrm{Mg}$ from upper to lower Horizons. Similarly, Xiaoning et al. (2002) and Sharma (2011) research has authenticated that through determined roots and nutrient status in the woodland of Hippophae rhamnoides plantations increased the percentage contents of exchangeable $\mathrm{Ca}$ and $\mathrm{Mg}$ in the topsoil and subsoil which in result improved soil fertility. Hence, seabuckthorn is well suited for high altitudes and plays an important role in improving the soil nutrient conditions (Zhang and Chen, 2007).
Effect on different vegetation types on soil nutrients: The content of soil $\mathrm{pH}$ was alkaline in case of seabuckthorn forest in comparison to willow forest and wasteland. In seabuckthorn forest contents of organic carbon, available $\mathrm{N}, \mathrm{S}$, exchangeable cations $\mathrm{Ca}$, $\mathrm{Mg}$ are in high rate, taking about (1.02-2.31 per cent, $122.7-199.3 \mathrm{~kg} \mathrm{ha}^{-1}, 24.7-49.0 \mathrm{~kg} \mathrm{ha}^{-1}, 8.53-1018 \mathrm{cmol}$ $\left(\mathrm{p}^{+}\right) \mathrm{kg}^{-1}, 2.1-3.4 \mathrm{cmol}\left(\mathrm{p}^{+}\right) \mathrm{kg}^{-1}$ as compared to the low rate in willow (0.96-2.29 per cent, $104.7-167.3 \mathrm{~kg} \mathrm{ha}^{-1}$, 20.7-43.3 $\mathrm{kg} \mathrm{ha}^{-1}, 7.35-10.00 \mathrm{cmol}\left(\mathrm{p}^{+}\right) \mathrm{kg}^{-1}, 1.9-3.0$ $\operatorname{cmol}\left(\mathrm{p}^{+}\right) \mathrm{kg}^{-1}$ and wasteland $(0.86-2.01$ per cent, 91.0 $157.3 \mathrm{~kg} \mathrm{ha}^{-1}, 18.0-42.0 \mathrm{~kg} \mathrm{ha}^{-1}, 6.50-9.62 \mathrm{cmol}\left(\mathrm{p}^{+}\right) \mathrm{kg}^{-}$ $\left.{ }^{1}, 1.7-3.1 \mathrm{cmol}\left(\mathrm{p}^{+}\right) \mathrm{kg}^{-1}\right)$ (Table 2). Results revealed that seabuckthorn has a profound effect on key soil properties including $\mathrm{pH}$, organic carbon and available nitrogen. The contents of soil organic carbon, available N, available $\mathrm{S}$ and exchangeable cations $\mathrm{Ca}$ and $\mathrm{Mg}$ were significantly greater in seabuckthorn forest than willow forest and wasteland (Table 2).

But the effects of available $\mathrm{P}$ and $\mathrm{K}$ in the forest of seabuckthorn are less stable than willow forest. In addition, available $\mathrm{P}$ and $\mathrm{K}$ contents in the forest of seabuckthorn are obviously higher than that in the wasteland. This proves that seabuckthorn plantation has indulged nutrients in the wasteland area and made it productive land, full of nutrients.

Soil nutrients varied greatly from seabuckthorn forest to willow forest and wasteland and from different altitudes in Spiti valley. This suggests that soil nutrient conditions were better in seabuckthorn forest than willow forest and wasteland. Also, an increasing trend of available nutrients (organic carbon, available $\mathrm{N}, \mathrm{P}, \mathrm{K}$, $\mathrm{S}$ and exchangeable $\mathrm{Ca}, \mathrm{Mg}$ ) was observed in relation to increasing altitudes i.e. greater amount of soil organic carbon, available $\mathrm{N}, \mathrm{P}, \mathrm{K}, \mathrm{S}$ and exchangeable cations $\mathrm{Ca}, \mathrm{Mg}$ were observed at higher altitudes as compared to lower altitudes (Table 2).

As indicated in Table 3, soil pH was found negatively and significantly correlated with both seabuckthorn forest and altitude. Organic carbon was found positively and significantly correlated with seabuckthorn forest and altitude. Also, available nutrients N, P, K and exchangeable cations $\mathrm{Ca}, \mathrm{Mg}$ were found positively and significantly correlated with seabuckthorn forest and altitude. The interaction between different altitudes and species was found significant at $5 \%$ level of significance for the soil organic carbon, available $\mathrm{N}, \mathrm{P}, \mathrm{K}$, $\mathrm{S}$ and exchangeable cations $\mathrm{Ca}, \mathrm{Mg}$.

Overall effect of seabuckthorn forest has played an obvious role in improvement of soil organic carbon and available nitrogen than willow forest and wasteland. As soil organic carbon and available $\mathrm{N}$ are the most important component of soil fertility and often used to assess the melioration. Similar results were supported by (Zhang and Chen, 2007; Mao et al., 2010; Sharma, 2011) who reported that seabuckthorn forest has higher values of soil organic carbon and 
available $\mathrm{N}$ than other landuse which further proves that seabuckthorn through its determined root system add nutrients in soil and leads to improvement in soil fertility. All these points in this study proved that seabuckthorn is an important plant species for conditioning the soil nutrients especially in cold desert regions. Hence, the differences of soil conditions in different forests reflected that there is need of forest transformation. However, effective planning and appropriate plantation is needed. As plantation of Hippophae rhamnoides is an effective way to accelerate forest growth, biomass production, species diversity, beneficial for soil physical and chemical properties, water conditions and nutrients. This implies future plantation of $H$. rhamnoides in cold deserts such as Spiti valley can play a significant role in combating soil erosion, enhancing soil quality and fertility.

\section{Conclusion}

This study revealed that the change in altitudinal pattern and $H$. rhamnoides had significant effect on certain chemical properties of soil. The effect of seabuckthorn forest on the soil nutrients is higher than those in the willow forest and wasteland. Especially seabuckthorn forest has an obvious role in improvement of organic carbon and the available $\mathrm{N}$ which are the leading factors in enhancing soil fertility. Proper management of the wasteland by plantation of seabuckthorn could conserve the soil health. Also, because of its attractive and tremendous properties it can be commercially exploited by the farmers which will ecologically benefit and conserve the environment and its services.

\section{ACKNOWLEDGEMENTS}

Special thanks to Department of Biology and Environmental Sciences and Department of Soil Sciences, CSKHPKV, Palampur.

\section{REFERENCES}

Acharya, S., Stobdan, T. and Singh, S.B. (2010). Seabuckthorn (Hippophae sp. L.): New crop opportunity for biodiversity conservation in cold arid Trans-Himalayas. Journal of Soil and Water Conservation, 9: 201-204.

Ali, H., Razaq, A., Perveen, S. and Khan, B. (2013). Nitrogen Fixation by non-leguminous plant seabuckthorn in semi arid climatic conditions of Gilgit- Baltistan. Pakistan Journal of Weed Sciences, 19: 305-314.

Anderson, S.C., Olsson, M.E., Johansson, E. and Rumpunen, K. (2009). Carotenoides in seabuckthorn (Hippophae rhamnoides L.) berries during ripening and use of pheophytin as a maturity maker. Journal of Agricultural and Food Chemistry, 57: 250-258.

Bi, Y. and Zhang, Y. (2014). Role of the different planting age of seabuckthorn forests to soil amelioration in coal mining subsidence land. International Journal of Coal Science and Technology, 1(2):192-197.

Biddapa, C.C. and Rao, V. (1973). Altitudinal pattern of soil characteristics under forest vegetation in Eastern Hima- layan region. Journal of Indian Society of Soil Science, 25: 21-42.

Gomez, K.A. and Gomez, A.A. (1984). Statistical procedures for agricultural research. Second Ed. John Wiley and Sons, New York, USA P. 680.

Gong, J., Chen, L.D., Fu, B.J. and Wei, W. (2007). Integrated effects of slope aspect and land use on soil nutrients in a small catchment in a hilly loess area China. International Journal of Sustainable Development and World Ecology, 14: 307-316.

Guo, Z.S. (2003). Seabuckthorn for the improvement of the microclimate and soil properties of mountainous wastelands in arid and semi-arid China. In: Singh, V.2003 (Editor-in-Chief). Seabuckthorn (Hippophae L.): A Multipurpose Wonder Plant, Indus pub. Co; New Delhi 1: 417-432.

Kallio, H., Yang, B. and Peippo, P. (2002). Effects of different origins and harvesting time on vitamin $\mathrm{C}$, tocopherols, and tocotrienols in seabuckthorn (Hippophae rhamnoides) berries. Journal of Agricultural and Food Chemistry, 50(21): 6136-6142.

Khan, B., Jasra, W.A. and Ali, H. (2015). Seabuckthorn- An ecosystem based adaptation strategyfor arid mountain areas of Pakistan. In: Proceedings $7^{\text {th }}$ Conference of the International seabuckthorn Association on "Seabuckthorn: Emerging technologies for Health Protection and Environmental Conservation" (V. Singh, Ed -in-Chief, 2015), New Delhi, India, pp.57-61.

Khosla, P.K., Sehgal, R.N., Sharma, V., Bhatt, A.K. and Singh, V. (1994). Genetic Resources of Seabuckthorn, Himachal Pradesh. A report of Seabuckthorn Task Force, Shimla, Himachal Pradesh 4: 2-3.

Kohler, T., Giger, M., Hurni, H., Ott, C., Weismann, U., Wymann, S., and Maselli, D. (2010). Mountain and climate change: A Global concern. Mountain Research and Development, 30(1):53-55.

Kumar, A., Guleria, S., Mehta, P., Walia, A., Chauhan, A. and Shirkot, C.K. (2015). Plant growth-promoting traits of phosphate solubilising bacteria isolated from Hippophae rhamnoides L. (Seabuckthorn) growing in cold desert Trans-Himalayan Lahaul and Spiti regions of India. Acta Physiologiae Plantarum, 37(3): 1-12.

Mao, R., Zeng D.H., Ai, G.Y., Yang, D., Li, L.J. and Liu, Y.X. (2010). Soil microbiological and chemical effects of a nitrogen-fixing shrub in poplar plantation in semiarid region of Northeast China. European Journal of Soil Biology, 46: 325-329.

Mishra, S., Dhyani, D. and Maikhuri, R.K. (2009). Understanding the role of Seabuckthorn in soil fertility improvement in central Himalayas, India. In: Seabuckthorn on the way between science and industry interaction $4^{\text {th }}$ International Association Conference, Russia. 14: 39.

Olsen, S.R., Cole, C.V., Watanave, F.S. and Dean, L.A. (1954). Estimation of available phosphorus in soils by extraction with sodium carbonate. United States Department of Agriculture, Citric. p 939.

Rongsen, L. (1992). Seabuckthorn- A Multipurpose Plant for Fragile Mountains. International Centre for Integarted Mountain Development ICIMOD. Occasional Paper No. 20. Kathmandu, Nepal p 62.

Rongsen, L. (2014). Studies on correlation of berry quality parameters of seabuckthorn in relation to increasing altitude in China. In: Seabuckthorn-A Multipurpose 
Wonder Plant Chemistry and Biochemistry (V. Singh, Ed. In Chief, 2014), pp: 281-285, Daya Publishing House, New Delhi, 610p.

Sharma, A. (2011). Impact assessment of seabuckthorn (Hippophae L.) on soil fertility status. M.Sc. Thesis, p 86. Department of Biology and Environmental Sciences, COBS, CSK Himachal Pradesh Krishi Vishvavidyalaya, Palampur, India.

Sharma, L.K., Rana, R.K., Singh, A. and Singh, V. (2015). Experiences on mass multiplication and systematic plantation of seabuckthorn in cold desert condition of Himachal Pradesh. In: Proceedings $7^{\text {th }}$ Conference of the International seabuckthorn Association on "Seabuckthorn: Emerging technologies for Health Protection and Environmental Conservation" (V. Singh, Ed -in-Chief, 2015), New Delhi, India, pp.57-61.

Sharma, V. and Kanwar, B.B. (2010). Copper status and its relation with soil properties in pea growing soils of high hills dry temperate zone of the Himachal Pradesh. Journal of Indian Society of Soil Science 44: 32-37

Singh, V. (2003). Seabuckthorn (Hippophae L.): A Multipurpose Wonder Plant Seabuckthorn (Hippophae L.) - A Multipurpose Shrub of Cold Desert of Himalayas. 48: 39.

Singh, R. and Gupta, M. (1990). Soil and vegetation study of Lahaul and Spiti cold desert of Western Himalayas. Indian Forester, 116(10): 785-790.

Singh, B. and Raman, S.S. (1982). Altitudinal pattern of the soil characteristics under forest vegetation in eastern Himalayan region. Journal of Indian Society of Soil Science 38: 93-99

Stobdan,T., Angchuk, D. and Singh, S.B. (2008). Seabuckthorn: an emerging storehouse for researchers in India. Current Science, 94: 1236-1237.

Tamchos, S. and Kaul, V. (2015). Seabuckthorn- the natural soil fertility enhancer. Current Science, 108(5): 763-
764.

Walkley, A. and Black, C.A. (1934). An estimation of the method for determination of soil organic matter and a proposed modification of the chromic acid titration method. Soil Science, 37: 29-39.

Xiaoning, T., Baoli, A., Xiufend, W. and Jing, N. (2002). Soil Improvement of Seabuckthorn (Hippophae rhamnoides) Plantations and its characteristics of the Roots in Loess Plateau. $12^{\text {th }}$ ISCO conference, China.

Yadav, K.A. and Deswal, R. (2007). Deciphering the low temperature tolerance in seabuckthorn. In: Proceedings of the $3^{\text {rd }}$ International Seabuckthorn Association Conference. (D.B. Mckenzie, Ed-in-Chief, 2007), Quebec City, Canada, pp. 47-56.

Yao, Y. and Tigerstedt, P.M.A. (1995). Geographic variation of growth rhythm, height and hardiness and their relations in Hippophae rhamnoides. Journal of the American Society for Horticultural Science, 120(4): 691-698.

Yu, X., Liu, X., Zhao, Z., Liu, J. and Zhang, S. (2015). Effect of Monospecific and Mixed Seabuckthorn (Hippophae rhamnoides) Plantations on the Structure and Activity of Soil Microbial Communities. PloS ONE, 10(2):1-11.

Zhang, J.T. and Chen, T. (2007). Effects of mixed Hippophae rhamnoides on community and soil in planted forests in the Eastern Loess Plateau, China. Ecological Engineering, 31: 115-121.

Zhao, G., Mu, X., Wen, Z., Wang, F., and Gao, P. (2013a). Soil erosion, conservation and ecoenvironment changes in the Loess Plateau of China. Land Degradation and Development, 24(5): 499-510.

Zhao, Z., Shahrour, I., Bai, Z., Fan. W., Feng, L. and Li, H. (2013b). Soils development in opencast coal mine spoils reclaimed for 1-13 years in the West-Northern Loess Plateau of China. European Journal of Soil Biology, 55: 40-46. 